\title{
United States backs climate panel findings
}

London. The US government last week condemned attempts by US energy interests to undermine the work of the Intergovernmental Panel on Climate Change (IPCC). Committing itself for the first time to binding targets to reduce greenhouse gas emissions, it said the science of climate change "cannot be ignored" and that human-induced global warming "cannot be wished away".

Timothy Wirth, US Under-Secretary of State for Global Affairs, said the findings of the IPCC had convinced the Clinton administration of the need to take steps to address global warming. Wirth was addressing the second annual conference of the United Nations climate convention in Geneva.

Wirth described as a "remarkable statement" the conclusion of the IPCC's latest report on climate change, that "the balance of evidence suggests that there is a discernible human influence on global climate". He said the administration took the report "very seriously".

Wirth described the IPCC's critics as "naysayers and special interests bent on belittling, attacking and obfuscating climate change science". John Shlaes, executive director of the Global Climate Coalition, the lobby group that has tried to discredit parts of the IPCC report, said the statement would cost the US "millions of jobs".

Wirth's speech initially delighted environmentalists at the Geneva conference. It also set the tone for an upbeat statement in which most of the 60 environment ministers present promised to start negotiations in December on an international law to bind countries to reducing carbon dioxide $\left(\mathrm{CO}_{2}\right)$ emissions by a specified quantity after 2000 .

But a closer reading of the speech also reveals the Clinton administration's terms for future US cooperation in climate negotiations. Wirth said that all present proposals to limit $\mathrm{CO}_{2}$ emissions were "neither realistic nor achievable". The Alliance of Small Island States (AoSIS) would like a 20 per cent reduction in $\mathrm{CO}_{2}$ emissions, compared to 1990 levels, by 2005, and Britain has suggested a 5-10 per cent cut by 2010 .

But environmentalist organizations, such as the Climate Action Network (CAN), say they will continue to push for the AoSIS proposal as the basis for future reductions targets. "Tactically, it's our best option," says Gurmit Singh, regional coordinator for CAN south-east Asia. "If we start with a weaker text, it's bound to get weaker still by the time it's agreed."

Wirth also emphasized that the United States would oppose any law binding countries to specific measures to reduce $\mathrm{CO}$, emissions. Furthermore, a long-term international agreement to reduce $\mathrm{CO}_{2}$ emissions, he added, would need to include commitments from developing countries.

The speech angered Russia, Australia and ten states belonging to the Organization of Petroleum Exporting Countries (OPEC). An OPEC statement said its members would lose US $\$ 190$ billion in oil export income if a carbon tax were introduced.

Developing countries also left Geneva concerned at the implications that $\mathrm{CO}_{2}$ reduction measures would have on their newly industrializing economies. The current climate convention asks that only developed countries reduce their $\mathrm{CO}_{2}$ emissions to 1990 levels by 2000 .

Li Zhaoxing, China's Vice-Foreign Minister and head of the country's delegation to the climate convention, said his government attaches "great importance" to climate change. But he also added that "China is a developing country whose first and overriding priorities are economic and social development; to eradicate poverty and to meet the basic needs of the people's livelihood".

Michael Grubb, head of the energy and environment programme at the Royal Institute for International Affairs in London, says that designing an agreement that includes developed and developing

\section{Lobbyists 'belittle climate change science'}

London. Timothy Wirth, US Under-Secretary of State for Global Affairs, opened his address to last week's climate conference (see above) with a strong defence of the Intergovernmental Panel on Climate Change (IPCC) against the "false" charges of scientific impropriety.

The US government was "not swayed by and strongly objected to" allegations made by groups such as the Global Climate Coalition (GCC) about the integrity of the IPCC's conclusions (see Nature 381, 546; 1996), Wirth said. "Let's take a false issue off the table. There can be no question but that the
IPCC's findings meet the highest standards of scientific integrity".

Ben Santer, an IPCC lead author and atmospheric physicist at the Lawrence Livermore Laboratory, California, who is at the centre of the controversy over the rewriting of a key chapter, says the statement amounts to "a ringing endorsement" of the IPCC.

Dana Rohrabacher, chair of the House Science Committee's energy and environment subcommittee, is considering convening congressional hearings at which Santer would be asked to explain his actions.

E. $\mathbf{M}$.

\author{
IMAGE \\ UNAVAILABLE \\ FOR COPYRIGHT \\ REASONS
}

Culture clash? China's development priorities seem odds with calls to limit carbon dioxide emissions.

countries "will be an extremely tough issue". The US government, says Grubb, understands it is inequitable to ask developing countries to reduce their $\mathrm{CO}_{2}$ emissions at a level comparable to the developed world. But he adds that the Clinton administration could not risk the potential political backlash at home if developing countries remained exempt.

Jake Werksman, of the Foundation for International Environmental Law and Development at the University of London, believes that the US government will "most likely" insist that developing countries sign up to an agreement that allows them to defer emission-reducing measures. "No developing country will be willing to sign up to anything stronger," he says.

The Wirth speech, an apparent reversal of US climate policy, is believed to reflect the growing confidence within the Clinton administration of victory at the November elections. But Rafe Pomerance, deputy assistant secretary for environment and development at the State Department who helped draft the statement, says the timing of its release is a coincidence. "The administration has been working on the policy for more than a year."

The speech caused further controversy over the absence of the word 'legal' before references to 'binding targets' to limit $\mathrm{CO}$ emissions. Singh and Grubb both feel that its absence is significant. But, whereas Grubb believes the omission is no more than "political sleight of hand" designed to pacify a potentially sceptical American public, Singh regards it as an "escape clause" designed to protect the United States from signing up to any law that could cause political difficulties at home.

Mark Hambley, a senior official with the US delegation to the Geneva talks, says the word's absence is "not an issue". He points out that the US government "wholeheartedly endorsed" the end-of-conference ministerial declaration that calls for "quantified legally-binding objectives for emissions limitations".

Ehsan Masood 